\title{
Ratlarda deneysel spinal kord yaralanmasında Hesperidin'in nöroprotektif etkisi
}

\author{
Neuroprotective effect of Hesperidin on experimental spinal cord injury in rats
}

Hasan Ali Aydın, Emrah Keskin

Gönderilme tarihi:14.01.2022

Kabul tarihi:02.02.2022

\section{Öz}

Amaç: Bu çalışmada, ratlarda deneysel omurilik yaralanmasında farklı dozlarda hesperidinin (HSP) oksidatif hasara karşı koruyucu etkisini histopatolojik ve biyokimyasal değerlendirmeler kullanarak araştırmayı amaçladık. Gereç ve yöntem: Çalışma 4 grup ve her grupta 10 adet Wistar albino cinsi rat olacak şekilde planlandı. Grup 1 (kontrol grubu): laminektomi yapıldı. Laminektomi sonrası üç gruba (G2, G3, G4) travma uygulandı. Grup 2 (patoloji grubu): laminektomi yapıldı ve ekstradural klip uygulandı. Grup 3 (düşük doz HSP): laminektomi yapılıp, ekstradural klip uygulandı ve tek doz düşük doz HSP intraperitoneal olarak verildi $(50 \mathrm{mg} / \mathrm{kg}$ ). Grup 4 (yüksek doz HSP): laminektomi yapılıp, ekstradural klip uygulandı ve tek doz yüksek doz HSP intraperitoneal olarak verildi (100 mg/kg). Nöroprotektif etkiyi değerlendirmek için alınan doku örnekleri biyokimyasal ve histopatolojik olarak incelendi.

Bulgular: Travma gruplarındaki inflamatuar bulgular ve nöron sayısının morfometrik sonuçları, Grup 4 'te diğer gruplara kıyasla istatistiksel olarak anlamlı şekilde daha iyiydi. Klinik motor muayene ve eğik düzlem test sonuçları açısından gruplar arasında fark yoktu. Her iki tedavi grubunda (Grup3, Grup4), lipid peroksidasyonunun son ürünü olan malondialdehit anlamlı bir farklılık gözlemlenmezken $(p>0,05)$; total antioksidan plazma seviyelerinde kontrol ve patoloji gruplarına kıyasla istatistiksel olarak anlamlı bir farklılık gözlemlendi $(p: 0,001)$.

Sonuç: Sonuçlarımız, yüksek doz HSP' nin spinal kord hasarında nöronların sayısındaki azalmaya olumlu etkisi ve hafif dejenerasyon bulguları ile neuroprotektif etki sağlayabileceğini düşündürmektedir.

Anahtar kelimeler: Hesperidin, spinal kord yaralanma, neuroprotektif etki.

Aydın HA, Keskin E. Ratlarda deneysel spinal kord yaralanmasında Hesperidin'in nöroprotektif etkisi. Pam Tıp Derg 2022;15:451-459.

\begin{abstract}
Purpose: In this study, we aimed to investigate the protective effect of different doses of Hesperidin (HSP) against oxidative damage in experimental spinal cord injury in rats using histopathological and biochemical evaluations.

Material and methods: The study was planned as four groups and 10 Wistar albino rats in each group. Group 1 (control group): laminectomy was performed. Trauma was applied to three groups (G2, G3, G4) after laminectomy. Group 2 (pathology group): laminectomy was performed, and an extradural clip was applied. Group 3 (low dose HSP): laminectomy was performed, an extradural clip was applied, and a single low dose HSP was administered intraperitoneally $(50 \mathrm{mg} / \mathrm{kg}$ ). Group 4 (high-dose HSP): laminectomy was performed, an extradural clip was applied, and a single high-dose HSP was administered intraperitoneally (100 mg/kg). Tissue samples taken to evaluate the neuroprotective effect were examined biochemical and histopathological.

Results: Morphometric results of inflammatory findings and neuron number in the trauma groups were significantly better in Group 4 than in the other groups. There was no difference between the groups regarding clinical motor examination and inclined plane test results. Malondialdehyde, the end product of lipid peroxidation, did not differ significantly in both treatment groups (Group3, Group4) ( $p>0.05)$; A statistically significant difference was observed in total antioxidant plasma levels compared to the control and pathology groups ( $p: 0.001)$.

Conclusion: Our results suggest that high-dose HSP may provide a neuroprotective effect with its positive impact on decreasing the number of neurons in spinal cord damage and mild degeneration findings.
\end{abstract}

Key words: Hesperidin, spinal cord injury, neuroprotective effect.

Aydin HA, Keskin E. Neuroprotective effect of Hesperidin on experimental spinal cord injury in rats. Pam Med J 2022;15:451-459.

Hasan Ali Aydın, Dr. Öğr. Üye. Zonguldak Bülent Ecevit Üniversitesi Tıp Fakültesi, Beyin ve Sinir Cerrahisi Anabilim Dalı, Zonguldak, Türkiye, e-posta: dr.hasanali61@hotmail.com (https://orcid.org/0000-0002-0883-4611)

Emrah Keskin, Dr. Öğr. Üye. Zonguldak Bülent Ecevit Üniversitesi Tıp Fakültesi, Beyin ve Sinir Cerrahisi Anabilim Dalı, Zonguldak, Türkiye, e-posta: drkeskinemrah@gmail.com (https://orcid.org/000-0001-5326-741X) (Sorumlu Yazar) 


\section{Giriş}

Travmatik omurilik hasarı kişisel, sosyal ve psikolojik etkileri, iş gücü kaybı, finansal sonuçları göz önüne alındığında ciddi bir halk sağlığı problemi olmaya devam etmektedir [1]. Majör omurilik yaralanmaları sonrasında beyindeki inen ve çıkan nöral sistemlerin omurilikteki bağlantıları bozulur ve lezyon altında değişen derecelerde motor ve duyu kaybı gelişir. Travmatik omurilik yaralanmasının dünyadaki yıllık görülme sıklığı milyonda 15-40 olarak bildirilmiştir [2]. Spinal kord yaralanmasının (SKY) patofizyolojisi akson, kan damarı ve hücre membranlarının hasarına neden olan primer hasar ile başlar. Birincil yaralanma mekanik hasarı ifade eder. Bu primer mekanik yaralanma ikincil hasar fazı ile devam eder. İkincil yaralanma ise travma sonrası ilerleyici hücre hasarını ve geç apopitotik hücre ölümü ile sonuçlanan süreci ifade eder [3,4]. Travma sonrası medulla spinaliste oluşan iskemi patogenezi için Hall ve Walf'un [5] hipotezleri halen geçerliliğini korumaktadır. Bu hipotezde medulla spinalis kan akımının azalmasında temel mediatör olarak mikrovasküler lipid peroksidasyonu görülmektedir. Serbest radikallerce indüklenen lipid peroksidasyonu ve nötrofillerden salınan oksijen radikalleri spinal kordun hasarlanmasında rol oynar.

Antioksidanlar ise etkilerini reaktif oksijen ürünleri (ROS)'nin oluşumunu önleyerek ve/ veya temizleyerek gösterirler. Eksojen kaynaklı antioksidanların birçoğu bugün yaygın olarak kullandığımız gıdalarda bulunmaktadır [6]. Flavonoidler de bu bileşikler arasındadır. Flavonoidlerin antioksidan özelliklerinin yanında antiinflamatuar, antiviral, antiallerjik, antitrombotik ve diğer özelliklerinin de bulunduğunu gösterilmiştir [7]. Hesperidin (HSP) turunçgillerde bol miktarda bulunan bir flavanon glikozit olup, bitki savunmasında rol oynadığına inanılmaktadır [8]. Bu bileşiğin, antioksidan ve anti-inflamatuar etkileri ile ilişkili olarak önemli bir nöroprotektif özelliğe sahip olduğunu ileri süren çalışmalar da mevcuttur $[9,10]$.

Bu çalışmada, ratlarda oluşturulan deneysel SKY'sında farklı dozlardaki HSP'nin, oksidatif hasara karşı koruyucu etkisini histopatolojik ve biyokimyasal olarak değerlendirdik.

\section{Gereç ve yöntem}

$\mathrm{Bu}$ deneysel çalışma Zonguldak Bülent Ecevit Üniversitesi Tıp Fakültesi Hayvan Deneyleri Yerel Etik Kurulu'nun Etik Kurulu'nun onayı alınarak; Zonguldak Bülent Ecevit Üniversitesi Tıp Fakültesi Deney Hayvanları Araştırma Laboratuvarı, biyokimya ve patoloji laboratuvarında gerçekleştirilmiştir. $350-450 \mathrm{~g}$ ağırlığındaki toplam 40 adet Wistar Albino cinsi erkek rat rastgele olarak eşit sayıda dört gruba ayrıldı ( $n=10$, toplam:40). Hayvanlar, deney süresince sabit bir sıcaklığın $\left(18^{\circ} \mathrm{C}-21^{\circ} \mathrm{C}\right)$ altında tutularak, yeterli beslenme ve fotoperiyod (12 saat aydınlık/karanlık döngüsü) sağlandı.

\section{Çalışma grupları}

Kontrol grubuna sadece laminektomi uygulandı. Laminektomi sonrası kalan üç gruba travma uygulandı. Grup 1: (kontrol grubu, n:10) spinal travma yapılmayan ve herhangi bir tedavi verilemeyen grup; Grup 2: (patoloji grubu, $\mathrm{n}: 10)$ spinal travma yapılan herhangi bir tedavi verilemeyen grup; Grup 3: (Düşük doz HSP, $\mathrm{n}: 10)$ spinal travma uygulanan ve düşük doz HSP verilen (50 mg/kg) grup; Grup 4: (Yüksek doz HSP, n:10) spinal travma uygulanan ve yüksek doz HSP verilen (100mg/kg) gruptu.

\section{Cerrahi prosedür}

Cerrahi işlem öncesi her deney hayvanına 10 $\mathrm{mg} / \mathrm{kg}$ intramüsküler ksilazin $(5 \mathrm{mg} / \mathrm{kg}$; Bioveta, Ankara, Türkiye) ve $80 \mathrm{mg} / \mathrm{kg}$ intramüsküler ketamin $\mathrm{HCl}$ (Pfizer, İstanbul, Türkiye) ile genel anestezi sağlandı. Lomber bölge traş edildikten sonra operasyon bölgesi povidon ile sterilize edildi. T5 ve T12 spinöz çıkıntıları arasında uzanan orta hat cilt insizyonu yapıldı. Lumbosakral fasya longitudinal olarak açıldı ve paraspinal kaslar T7-T10 laminasını ortaya çıkarmak için bilateral olarak subperiostal olarak diseke edildi. T7-T10 laminektomi ve flavektomi sonrası epidural yağ dokusu çıkarıldı ve dura mater açığa çıkarıldı. Bu işlemler sırasında dural defekt gözlenmedi. Bipolar koter ile hemostaz sağlandı. Epidural boşluk, standart spinal travma modeline (Rivlin ve Tator [11]; spinal kord travma modeli) uyacak şekilde lateral olarak genişletildi. Grup 2, 3 ve 4'teki ratların T9 seviyesinde spinal kordu mikroskop altında anevrizma klibi kullanılarak 1 dakika süreyle hasarlandı (Yasargil FE 750, Valley, Aesculap, PA, USA) (Şekil 1). Travma sonrası tabakalar 
anatomik planda kapatılarak ratların normal şekilde uyandırılması sağlanarak cerrahi işlem sonlandırıldı. Cerrahi prosedürün herhangi bir aşamasında dura hasarı gözlenen denekler çalışma dışında bırakıldı. İşlem sonunda Grup 3 deneklere $50 \mathrm{mg} / \mathrm{kg}$ HSP intraperitoneal olarak uygulandı. Aynı şekilde Grup 4 deneklere $100 \mathrm{mg} / \mathrm{kg}$ HSP intraperitoneal olarak uygulandı. Ratlar ameliyattan 24 saat sonra öldürücü dozda pentobarbital (200 mg/kg, Bioveta, Ankara, Türkiye) ile sakrifiye edildi. Ardından cerrahi alan yeniden açıldı ve hasarlanmış omurilik dikkatlice çıkarıldı. Çıkarılan omurilik örnekleri biyokimyasal ve histopatolojik açıdan değerlendirildi.

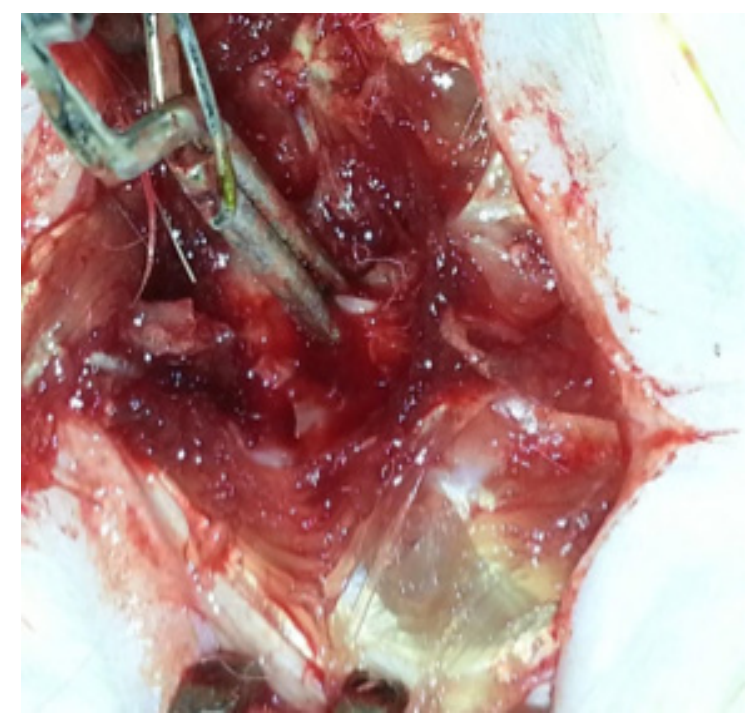

Şekil 1. Cerrahi işlem sırasında anevrizma klibi ile T9 seviyesindeki omurilik kompresyonunu gösteren intraoperatif fotoğraf

\section{Klinik motor muayene}

Çalışmamızda, Rivlin ve Tator [11] tarafından tarif edilen eğik düzlem testi kuyruk üzerine ağrılı uyaran uygulanarak yapılarak ratlarda fonksiyonel düzelme değerlendirildi. Periyodik olarak (8 saatte bir) klinik motor muayene yapıldı.

\section{Biyokimyasal değerlendirme}

Biyokimyasal veriler, travmatik spinal kord dokusundaki Malondialdehit (MDA) düzeyleri ve Total Antioksidan Seviye (TAS) ölçülerek elde edildi.

MDA çalışması: Serum ve doku MDA düzeyleri yüksek performanslı Sıvı kromatografisi (HPLC) yöntemiyle Agilent 1200 markalı HPLC (Münih, Almanya) cihazında Immundiagnostik markalı MDA'nın ticari kitleri (Bensheim, Almanya) kullanılarak çalışıldı. Çalışmanın prensibi derivasyon reaktifi ile yapılan örnek hazırlama işlemi sonucu MDA floresan bir ürüne çevrilmesine dayanır. Floresan ürüne çevrilen MDA içeren $20 \mu \mathrm{l}$ reaksiyon karışımı $30^{\circ} \mathrm{C}$ 'de reverse faz $\mathrm{C} 18$ kolon kullanılarak ayrıştırılması sonrası $515 \mathrm{~nm}$ eksitasyon ve $553 \mathrm{~nm}$ emisyonda florometrik ölçümü yapılır. Yöntemin dedeksiyon limiti $0,15 \mu \mathrm{mol} / \mathrm{L}$ ve linearitesi 100 umol/L'dir.

TAS çalışması: Serum ve doku total antioksidan seviyesi Immun Diagnostic (Bensheim, Germany) firmasının ticari ImAnOx (TAS/TAC) kiti ile çalışıldı. Bu testin ölçüm prensibi bilinen miktarda ekzojen hidrojen peroksidin örneğe eklenmesi sonrası örnekteki antioksidanlar ile hidrojen peroksidin reaksiyonuna dayanır. Örnekteki antioksidanlar eklenen hidrojen peroksidin belirli bir kısmını uzaklaştırır, artan hidrojen peroksit enzimatik reaksiyon ile TMB'yi renkli bir bileşiğe dönüştürür. Oluşan renkli bileşik fotometrik yöntemle ölçülür.

ELISA okuyucu cihazında $450 \mathrm{~nm}$ 'de enzim içeren örnekler ile enzim içermeyen örneklerin absorbansları alındı. Sonuçlar enzim içermeyen örneğin/kalibratörün optik dansitesinden enzim içeren örneğin/kalibratörün optik dansitesinin çıkarılması sonrası elde edilen delta optik dansite ( $\triangle O D$ örnek/kalibratör) kullanılarak hesaplandı.

\section{Histopatolojik ve morfometrik değerlendirme}

Histolojik incelemeler amacıyla, spinal kord örnekleri nötral tamponlu \%10'luk formalin solüsyonunda fikse edilerek 1 hafta buzdolabında $4^{\circ} \mathrm{C}$ 'de saklandı ve daha sonra taze fiksatife alındı. Fikse doku örnekleri parafine gömülerek, mikrotom ile horizontal düzlemde 5 mikron kalınlığında kesildi. Her örnekten hasarlı kord segmentinin ortası merkez alınarak üç düzeyde kesitler elde edildi: (i) hasarlı kord segmentinin tam ortası, (ii) $3 \mathrm{~mm}$ rostrali ve (iii) $3 \mathrm{~mm}$ kaudali. Lam üzerine alınan kesitler hematoksilen ve eozin (H\&E) yardımıyla boyanarak ışık mikroskobunda ödem, konjesyon, hemoraji, nöronal dejenerasyon ve nöron kaybı açısından değerlendirildi. Hasarlı kord segmentinin orta kısmından elde edilen kesitler, ayrıca kristal viyole ile boyanarak, görüntü analizi programı ile (Leica QWINPlus v.3.1.0; Leica, Solms, Germany) nöron kaybı 
açısından incelendi. Her kesitte gri maddede rasgele 10 alan seçilerek $\mathrm{X} 100$ 'lük büyütmede nöron sayıları belirlendi.

Çalışmanın istatistiksel analizleri SPSS 19.0 paket programında yapılmıştır. Veri setinde yer alan sürekli değişkenlere ait tanımlayıcı istatistikler ortalama, standart sapma, medyan, minimum ve maksimum değerleriyle; kategorik değişkenler frekans ve yüzde ile gösterilmiştir. Sürekli değişkenlerin normal dağılıma uygunlu ShapiroWilk testi ile incelenmiştir. Normal dağılım gösteren değişkenlerin 4 grup karşılaştırmalarında tek yönlü varyans analizi (ANOVA), anlamlı çıkan değişkenlerin 2'li alt grup karşılaştırmalarında Tukey testi kullanılmıştır. Normal dağılım göstermeyen değişkenlerin 4 grup karşılaştırmalarında Kruskal Wallis testi, 2 grup karşılaştırmalarında Mann Whitney U testi kullanılmıştır. Çalışmadaki tüm istatistiksel karşılaştırmalarda $p$ değeri 0,05 'in altındaki karşılaştırmalar istatistiksel olarak anlamlı kabul edilmiştir.
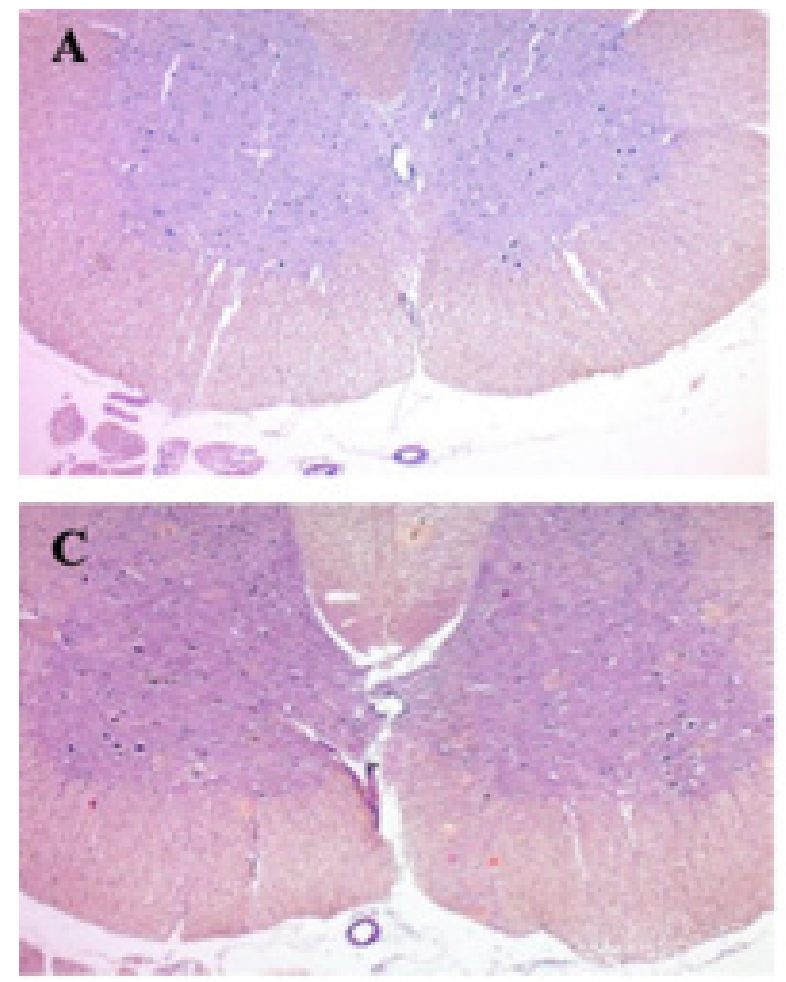

\section{Bulgular}

\section{Biyokimyasal değerlendirme sonuçları}

Oksidan ve antioksidan durumu ile ilgili biyokimyasal sonuçlar Tablo 1'de gösterilmiştir. Gruplar arasında medyan serum MDA değerleri yönünden istatistiksel olarak anlamlı farklılık görülmedi $(p>0,05)$. Grup 3 ve Grup 4'ün Serum TAS değerlerinde kontrol ve patoloji gruplarına kıyasla istatistiksel olarak anlamlı bir azalma olduğu görüldü $(p<0,001)$.

\section{Histopatolojik değerlendirme sonuçları}

Histolojik değerlendirmede Grup1'de normal spinal kord dokusuna ait histolojik görünüm izlendi (Şekil 2A). Patoloji grubunda ödem ve hemoraji ile birlikte gri maddede belirgin nöronal dejenerasyon görüldü (Şekil 2B). Grup 3 ve Grup 4'de hafif derecede ödem ve konjesyonun yanı sıra kısmi nöronal dejenerasyon bulguları izlendi (Şekil 2C, 2D).
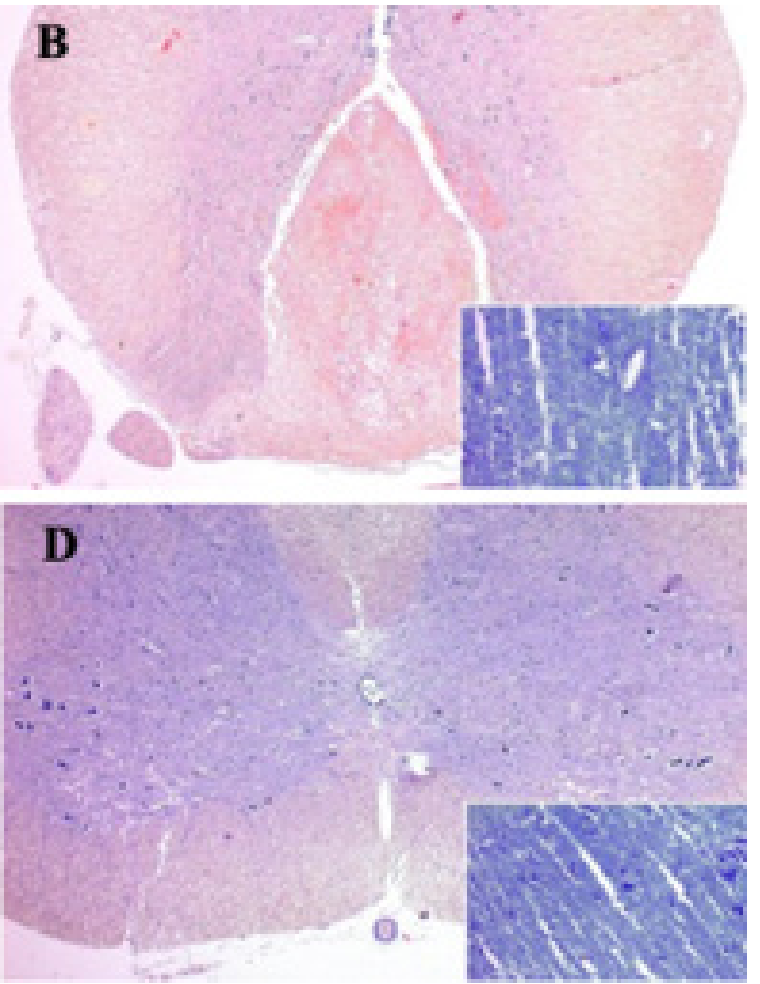

Şekil 2A. Grup 1'de nöronların düzenli dağılım gösterdiği normale yakın histolojik özelliklerin izlendiği spinal kordun mikroskobik görünümü (H\&E; X100); 2B. Grup 2'de ödem, hemoraji ve gri maddede belirgin nöronal dejenerasyon (H\&E; X100) - (sağ alt köşede nöron hücre kaybı kristal viyole boyası ile gösterilmiştir); 2C. Grup 3 nöron dejenerasyonunda ve hücre kaybında Grup 2'ye kıyasla göreceli azalma (H\&E; X100); 2D. Grup 4'de dejeneratif değişikliklerde ve hücre kaybında göreceli azalma (H\&E; X100) - (sağ alt köşede nöron hücre kaybı kristal viyole boyası ile gösterilmiştir) 


\section{Morfometrik sonuçlar}

Yapılan incelemede nöron sayıları ile ilgili değerler Tablo 2'de verilmiştir. Nöron sayıları gruplar arası karşılaştırıldığında; Grup 1 ile Grup 4 arasında, Grup 2 ve Grup 3 arasında istatistiksel olarak anlamlı fark bulunmamıştır (sırasıyla $p=0,442, p=0,234$, Tablo 2). Grup 1'e kıyasla Grup 2 ve Grup 3'te istatistiksel olarak anlamlı şekilde nöron sayısı azalmıştır (sırasıyla, $p=0,021, p=0,028$, Tablo 2). Ancak, Grup 4'deki deneklerde Grup 2 ve Grup 3'teki deneklere kıyasla nöron sayılarında anlamlı artış olduğu gözlendi (sırasıyla, $p=0,015, p=0,038$, Tablo 2).

Tablo 1. Serum MDA ve TAS değerleri

\begin{tabular}{llllll}
\hline & Grup 1 & Grup 2 & Grup 3 & Grup 4 & $\boldsymbol{p}$ \\
\hline Serum & 1,92 & 1,94 & 2,40 & 1,85 & 0,582 \\
MDA & $(1,36-3,32)$ & $(1,52-2,84)$ & $(1,61-4,35)$ & $(1,58-2,78)$ & \\
Serum & & & & & \\
TAS & $272,29 \pm 33,94$ & $300,13 \pm 24,58$ & $148,13 \pm 35,20$ & $162,13 \pm 27,88$ & $<0,001$ \\
\hline
\end{tabular}

MDA: Malondialdehit, TAS: Total Antioksidan Seviye

Tablo 2. Tüm Grupların nöron sayılarının analiz sonuçları

\begin{tabular}{lll}
\hline Grup & Denek sayısı & Nöron sayısı \\
\hline G1 & 10 & $16,25 \pm 3,59^{\mathrm{a}, \mathrm{b}, \mathrm{c}}$ \\
G2 & 10 & $11,03 \pm 2,57^{\mathrm{a}, \mathrm{d}, \mathrm{e}}$ \\
G3 & 10 & $12,1 \pm 2,37^{\mathrm{b}, \mathrm{d}, \mathrm{f}}$ \\
G4 & 10 & $14,9 \pm 3,01^{\mathrm{c}, \mathrm{e}, \mathrm{f}}$ \\
\hline
\end{tabular}

Ortalama \pm standart sapma olarak verilen veriler. $P$ 0,05 düzeyinde anlamlı; a: $\mathrm{G} 1$ ve $\mathrm{G} 2$ arasında $(p=0,021)$; b: $\mathrm{G} 1$ ve $\mathrm{G} 3$ arasında $(p=0,028)$; c: G1 ve G4 arasında ( $p=0,442)$; d: G2 ve G3 arasında ( $p=0,234)$; e: $\mathrm{G} 2$ ve $\mathrm{G} 4$ arasında $(p=0,015) ;$ f: $\mathrm{G} 3$ ve $\mathrm{G} 4$ arasında $(p=0,038)$

\section{Tartışma}

SKY fiziksel, duygusal ve ekonomik boyutu ile toplumun geniş bir kesimini etkilemektedir. 1950'lerden bu yana rehabilitasyon tedavisinin sürekli olarak gelişmesine rağmen, spinal kord hasarının iyileştirici bir tedavisi yoktur [12, 13]. Deneysel omurilik kontüzyonu modelleri sıklıkla SKY' sının patofizyolojisini anlayarak etkili tedavi yöntemleri geliştirmeyi hedeflemektedir [14]. Bu çalışmada deneysel SKY modelimizde HSP'nin gerek biyokimyasal gerek ise histopatolojik etkilerini inceledik.

SKY, lokal ve sistemik sekonder mekanizmaları tetikleyerek, esas olarak yaygın hücre ölümünden sorumlu olan kronik bir inflamatuar duruma neden olur [15]. Omurilik yaralanmalarında birincil yaralanmayı önlemenin imkânsız olmasından dolayı araştırmacıların geliştirmeye çalıştığı tedavi stratejileri ikincil yaralanmaları önlemeyi amaçlamaktadır [16]. Erken evrede, klinikte omurilik yaralanmasının geleneksel tedavisi, yüksek dozlarda metilprednizolon (MP) ile kombine cerrahi tedavidir [17]. MP'nun omurilik kan akışını arttırmak ve inflamatuar yanıtı sınırlamak gibi birçok avantajı olmasına rağmen, potansiyel zararları da mevcuttur. Güncel kılavuzların çoğu, akut SKY için rutin MP uygulamasını önermemektedir [18, 19]. $\mathrm{Bu}$ nedenle, SKY için farklı terapötik ajanlar (baicalein, graviola, melatonin gibi) deneysel çalışmalarda araştırılmaya devam etmektedir [20-22].

Antioksidatif, anti-inflamatuar, antimutajenik ve anti-kanserojen özellikler, temel hücresel enzim fonksiyonlarını modüle etme kapasiteleri olmasından dolayı polifenolik yapıya sahip flavonoidler de SKY tedavisi için araştırılan bileşikler arasındadır [23]. HSP (Hesperetin 7-O-rutinosit veya Hesperitin7-rhamnoglucoside), birçok turunçgil bitkisi tarafından ikincil bir metabolit olarak sentezlenen bir biyoflavonoiddir ve bu bitkilerin meyve sularında ve kabuklarında bol miktarda bulunur [24]. HSP antiinflamatuar etkilerinin yanında apoptoz, enfeksiyon, oksidatif stres, nörotoksisiteye karşı aktif olduğu bildirilmiştir [25-27]. Çalışmamızda HSP'nin spinal kord yaralanmasında antiinflamatuar, anti-oksidan ve nöroprotektif etkisini ortaya koymayı amaçladık. 
Inflamasyon, zararlı uyaranlara ve doku hasarına yanıt olarak ortaya çıkan bir savunma mekanizmasıdır. Nörolojik, kardiyovasküler, gastrointestinal, sağlık bozukluklarının ana nedeni uzun süreli inflamasyondur [28]. Yapılan bazı çalışmalarda, inflamasyonun nöral doku onarımını bloke etmede de önemli bir rol oynadığını; serbest radikal oluşumu ve lipid peroksidasyonu, omurilik nöronlarının oksidatif ölümüne neden olduğu, omurilik kan akışını azalttığı; vasküler değişikliklerin ödeme, nekroz ve iskemiye yol açtığı gösterilmiştir [29, 30].

Flavonoidlerin antiinflamatuar aktivitelerinde yer alan moleküler mekanizmaların siklooksijenaz-2, lipoksijenaz ve indüklenebilir NO sentaz gibi proinflamatuar enzimlerin inhibisyonu, NF-kB'nin inhibisyonu ve aktive edici protein-1 ve faz II antioksidan detoksifiye edici enzimlerin, mitojenle aktive olan protein kinazın, protein kinaz C'nin ve nükleer faktöreritroid 2-ilişkili faktör 2'nin aktivasyonu olduğu öne sürülmüştür $[19,20]$. SKY'sı sonrası flavanoidlerin nöroprotektif özellikleri, miyelin akson kaybını, glial skar oluşumunu ve astrosit proliferasyonunu azaltarak gösterdiği belirtilmiştir. Ayrıca, flavonoidler spinal kordda beyin kaynaklı nörotrofik faktör ve glial hücre dizisinden türetilmiş nörotrofik faktör gibi nörotrofik faktörler artırabilir ve büyüme sinyal yolunun deaktivasyonunu azaltabilir [17]. SKY sonrası lipid peroksidasyon ölçümü yapılan bir çalışmada MDA düzeylerine erken dönemde (travmadan $1 \mathrm{dk}$., $15 \mathrm{dk}$., $1-2$ ve 4 saat sonra) bakılmış ve MDA düzeyinin $15 \mathrm{dk}$. sonra artmaya başladığını, 1.saatte maksimuma ulaştığını ve daha sonra düştüğünü göstermişler [31].

Flavonoid olan icariinin, omurilik yaralanmasından sonra inflamasyonu, lipid peroksidasyonunu ve apoptozu önleyebildiğini, omuriliğin histopatolojik hasarını azaltabildiğini, motor fonksiyonunu iyileştirebildiğini, omurilik dokusunu etkili bir şekilde koruyabildiğini ve belirgin bir nöroprotektif etkiye sahip olduğunu göstermişler [32]. Wang ve ark. [33] SKY sonrası fonksiyonel iyileşme, kavite oluşumu, astrosit aktivasyonu ve sinir rejenerasyonunda bir flavonoid olan quercetin'in rollerini belirlemek için yaptıkları çalışmada quercetinin akut SKY'den sonra lokomotor ve elektrofizyolojik fonksiyonel iyileşmeyi, astrosit aktivasyonunu ve aksonal rejenerasyonu teşvik ettiğini bulmuşlardır. Antioksidan içeren bir flavon olan chrysinin, antiapoptotik özelliğinin, bir sıçan SKY modelinde SKY'nin neden olduğu nörolojik defisitleri azaltmak için endojen biyobelirteçlerin modülasyonu ve nöronal apoptoz yoluyla hem motor hem de duyusal fonksiyonların iyileşmesini desteklediğini gösterilmiştir [34]. Öztanır ve ark. [35] global serebral iskemi-reperfüzyon modeli uyguladıkları çalışmasında HSP tedavisinin oksidatif etkileri önemli ölçüde tersine çevirdiği ve nörodejeneratif histopatolojinin gelişimini engellediğini göstermişlerdir. Bu etkinin HSP'nin muhtemelen güçlü antioksidan ve serbest radikal süpürücü özelliklerinin bir sonucu olduğunu ifade etmişlerdir. Sisplatinin yarattığı oksidatif stresin santral ve periferik sinir sistemi üzerine toksik etkiye HSP'in eklenmesiyle antioksidan enzim seviyelerinin artırdığı, Tiyobütirikasit reaktif madde seviyelerini, elektromyelografi değişikliklerini ve dokudaki histolojik değişiklikleri azalttığı belirtilmiş ve bu durumun HSP'in antioksidan, antiinflamatuar serbest radikalleri temizleyebime özelliğinden kaynaklanabileceği vurgulanmıştır [36].

Litaratürde yapılan çalışmalarda HSP'nin antioksidan etkisi biyokimyasal parametreler ile gösterilmiş olmasına rağmen bizim yaptığımız çalışmanın biyokimyasal incelemelerinde (MDA, TAS) istatistiksel olarak anlamlı sonuç elde edilememiştir. Bu durum, HSP'nin çalışma esnasında uygulama dozunun ve uygulama zamanının farklılığı ile ilgili olabileceği veya antioksidan etkisini, incelediğimiz biyokimyasal parametrelerden farklı parametreler üzerinden gösterdiği veya çalışılan parametrelerin antioksidan etkinin gösterilmesinde yeterli olamayabileceği sonucuna vardık. Tamilselvam ve ark. [27] insan nöroblastom SK-N-SH hücrelerinde rotenon kaynaklı apoptoza karşı HSP'nin nöroprotektif etkilerini araştırmak için yaptıkları bu çalışmada HSP'nin bir nöroblastom hücre hattında antioksidan, mitokondriyal fonksiyonun korunması ve antiapoptotik özellikleri nedeniyle rotenona karşı nöroprotektif etkisini uyguladığını göstermişlerdir. Ishola ve ark. [37] ise çalışmalarında HSP takviyesi alan sineklerin, yalnızca gıda ortamında yetiştirilen sineklere kıyasla yumurtlama, larva hareketliliği ve tırmanma aktivitesinde doza bağlı bir artış sebebi ile HSP'nin Parkinson ve Alzhemier patogenezinin iyileştirilmesinde potansiyel bir nöroprotektif ajan olabileceği sonucuna varmışlardır. Başka bir deneysel çalışmada ise, paklitaksel kaynaklı periferik nöropati sonucu 
gelişen nöropatik ağrıyı HSP'nin hafifletebileceği sonucuna varılmıştır [38]. Ek olarak toksisite üzerine etkileri ile ilgili bir çalışmada, bir insektisit olan Emamectin Benzoate bağlı sıçanların beyninde oluşan toksik etkilere HSP'nin koruyucu etkileri olduğu görülmüştür [39]. SKY kaynaklı motor disfonksiyonu ve nöro-patolojik dejenerasyonu iyileştirip iyileştirmediğini değerlendirmek için yapılan bir çalışmada HSP'in nöropatolojik değişiklikleri (kanama, inflamatuar hücre infiltrasyonu ve doku kaybı gibi) ve tümör nekrotik faktör-a ve interlökin-1 $\beta$ dâhil olmak üzere proinflamatuar sitokinleri azalttığını ek olarak, süperoksit dismutaz, katalaz, nükleer faktör eritroid 2-ilişkili faktör-2 ve heme oksijenaz-1 gibi oksidatif stres ile ilgili moleküllerinde HSP tedavisi ile arttığı görülmüştür. Bu bağlamda, heme oksijenaz-1'in eşzamanlı yukarı regülasyonu ile lökomotor fonksiyonunun iyileşmesinin ve doku onarımının hızlandığı görülmüştür [40]. Yurtal ve ark. [41] yapmış olduğu çalışmada HSP'in, omurilik yaralanmasını takiben akut dönemde antioksidan, anti-inflamatuar ve antiapoptotik etkiler gösterdiğini; bu nedenle HSP'in SKY'sında nöroprotektif ve terapötik etkinlik gösterdiğini ifade etmişlerdir. Çalışmamızda histopatolojik olarak G3 ve G4'te ödem ve konjesyonu G1 ve G2'ye kıyasla daha az gözlemledik. Ayrıca nöron sayılarında azalma G4'te en az gözlenirken; bu azalmanın istatistiksel olarak ta gerek G2 gerek ise G3'ye kıyasla anlamlı olduğunu gözlemledik (sırasıyla, $p=0,015, p=0,038$, Tablo 2).

Sonuç olarak, tüm bu bulgular ışığında HSP'nin, SKY'sında sekonder hasarın önlenmesinde olumlu etkileri sebebiyle nöroprotektif ve terapötik etkinliği olduğu söylenebilir.

Çıkar ilişkisi: Yazarlar herhangi bir çıkar çatışması bildirmemektedir.

\section{Kaynaklar}

1. Hachem LD, Ahuja CS, Fehlings MG. Assessment and management of acute spinal cord injury: from point of injury to rehabilitation. J Spinal Cord Med 2017;40:665675. https://doi.org/10.1080/10790268.2017.1329076

2. Sekhon LH, Fehlings MG. Epidemiology, demographics, and pathophysiology of acute spinal cord injury. Spine 2001;26:2-12. https://doi.org/10.1097/00007632200112151-00002
3. Katoh H, Yokota K, Fehlings MG. Regeneration of spinal cord connectivity through stem cell transplantation and biomaterial scaffolds. Front Cell Neurosci 2019;13:248. https://doi.org/10.3389/fncel.2019.00248

4. Dimitrijevic MR, Danner SM, Mayr W. Neurocontrol of movement in humans with spinal cord injury. Artif Organs 2017;39:823-833. https://doi.org/10.1111/ aor.12614

5. Hall ED, Wolf DL. A pharmacological analysis of the pathophysiological mechanisms of posttraumatic spinal cord ischemia. J Neurosurg 1986;64:951-961. https://doi.org/10.3171/jns.1986.64.6.0951

6. Stavric B. Role of chemopreventers in human diet. Clin Biochem 1994;27:319-332. https://doi. org/10.1016/0009-9120(94)00039-5

7. Rashid $\mathrm{MI}$, Fareed $\mathrm{MI}$, Rashid $\mathrm{H}$, et al. Flavonoids and their biological secrets. Plant and Human Health 2019;2:579-605. https://doi.org/10.1007/978-3-03003344-6_24

8. Hirata A, Murakami Y, Shoji M, Kadoma Y, Fujisawa $S$. Kinetics of radical-scavenging activity of hesperetin and hesperidin and their inhibitory activity on COX-2 expression. Anticancer Res 2005;25:3367-3374.

9. Nones J, de Sampaio E Spohr TCL, Gomes FCA. Hesperidin, a flavone glycoside, as mediator of neuronal survival. Neurochem Res 2011;36:17761784. https://doi.org/10.1007/s11064-011-0493-3

10. Hajialyani M, Hosein Farzaei M, Echeverría J, Nabavi SM, Uriarte E, Sobarzo Sanchez E. Hesperidin as a neuroprotective agent: a review of animal and clinical evidence. Molecules 2019;24:648. https://doi. org $/ 10.3390 /$ molecules 24030648

11. Rivlin AS, Tator $\mathrm{CH}$. Effect of duration of acute spinal cord compression in a new acute cord injury model in the rat. Surg Neurol 1978;10:38-43.

12. Donnelly DJ, Popovich PG. Inflammation and its role in neuroprotection, axonal regeneration and functional recovery after spinal cord injury. Exp Neurol 2008;209:378-388. https://doi.org/10.1016/j. expneurol.2007.06.009

13. Tator $\mathrm{CH}$, Fehlings MG. Review of the secondary injury theory of acute spinal cord trauma with emphasis on vascular mechanisms. J Neurosurg 1991;75:15-26. https://doi.org/10.3171/jns.1991.75.1.0015

14. Young W. Spinal cord contusion models. Prog Brain Res 2002;137:231-255. https://doi.org/10.1016/s00796123(02)37019-5

15. Kang $Y$, Ding $H$, Zhou $H$, et al. Epidemiology of worldwide spinal cord injury: a literature review. J Neuro-Oncol 2018;6:1-9. https://doi.org/10.2147/ JN.S143236

16. Sengul G, Coban MK, Cakir M, et al. Neuroprotective effect of acute interferon-beta 1B treatment after spinal cord injury. Turk Neurosurg 2013;23:45-49. https://doi. org/10.5137/1019-5149.JTN.6651-12.1 
17. Zhang $\mathrm{P}$, Hölscher $\mathrm{C}, \mathrm{Ma} \mathrm{X}$. Therapeutic potential of flavonoids in spinal cord injury. Rev Neurosci 2017;28:87-101. https://doi.org/10.1515/ revneuro-2016-0053

18. Hurlbert RJ. Methylprednisolone for the treatment of acute spinal cord injury: point. Neurosurgery 2014;61:3235. https://doi.org/10.1227/NEU.0000000000000393

19. Walters BC, Hadley MN, Hurlbert RJ, et al. Guidelines for the management of acute cervical spine and spinal cord injuries: 2013 update. Neurosurgery 2013;60:82-91. https://doi.org/10.1227/01.neu.0000430319.32247.7f

20. Keskin E, Elmas Ö, Şahin Keser HH, Guven B. Efficacy of Annona muricata (graviola) in experimental spinal cord injury: biochemical and histopathological analysis. Ulus Travma Acil Cerrahi Derg 2022;28:233-241. https://doi.org/10.14744/tjtes.2021.70728

21. Zhao $R$, Wu $X, B i X Y$, Yang $H$, Zhnag Q. Baicalin attenuates blood-spinal cord barrier disruption and apoptosis through PI3K/Akt signaling pathway after spinal cord injury. Neural Regen Res 2022;17:10801087. https://doi.org/10.4103/1673-5374.324857

22. Egemen E, Öcal Ö, Börcek AÖ, et al. lyonize radyasyon sonrası gelişen oksidatif beyin ve spinal kord hasarını iyileştirmede deksametazon ve melatoninin etkilerinin sıçan modelinde karşılaştırılması. Sinir Sistemi Cerrahisi Derg 2021;7:83-95. https://doi.org/10.54306/ SSCD.2021.18189

23. Metodiewa D, Kochman A, Karolczak S, et al. Evidence for antiradical and antioxidant properties of four biologically active $\mathrm{N}, \mathrm{N}$-diethylaminoethyl ethers of flavanone oximes: a comparison with natural polyphenolic flavonoid (rutin) action. Biochem Mol Biol Int 1997;41:1067-1075. https://doi. org/10.1080/15216549700202141

24. Iglesias DJ, Cercos M, Colmenero Flores JM, et al. Physiology of citrus fruiting. Braz J Plant Physiol 2007;19:333-362. https://doi.org/10.1590/S167704202007000400006

25. Loguercio C, D’Argenio G, Delle Cave M, et al. Direct evidence of oxidative damage in acute and chronic phases of experimental colitis in rats. Dig Dis Sci 1996;41:1204-1211. https://doi.org/10.1007/ BF02088238

26. Galati EM, Monforte MT, Kirjavainen S, Forestieri AM, Trovato A, Tripodo MM. Biological effects of hesperidin, a citrus flavonoid. (Note I): antiinflammatory and analgesic activity. Farmaco 1994;40:709-712.

27. Tamilselvam K, Braidy N, Manivasagam $T$, et al. Neuroprotective effects of hesperidin, a plant flavanone, on rotenone-induced oxidative stress and apoptosis in a cellular model for Parkinson's disease. Oxid Med Cell Longev 2013;2013:102741. https://doi. org/10.1155/2013/102741
28. Ashley NT, Weil ZM, Nelson RJ. Inflammation: mechanisms, costs, and natural variation. Annual Review of Ecology, Evolution, and Systematics 2012;43:385-406. https://doi.org/10.1146/annurevecolsys-040212-092530

29. Bareyre FM, Schwab ME. Inflammation, degeneration and regeneration in the injured spinal cord: insights from DNA microarrays. Trends Neurosci 2003;26:555563. https://doi.org/10.1016/j.tins.2003.08.004

30. Toborek M, Malecki A, Garrido R, Mattson MP, Hennig B, Young B. Arachidonic acid-induced oxidative injury to cultured spinal cord neurons. J Neurochem 1999;73:684-692. https://doi.org/10.1046/j.14714159.1999.0730684.x

31. Barut S, Canbolat A, Bilge T, Aydin Y, Çokneşeli B, Kaya $U$. Lipid peroxidation in experimental spinal cord injury: time-level relationship. Neurosurg Rev 1993;16:53-59. https://doi.org/10.1007/BF00308614

32. Ren XS, Ding W, Yang XY. Neuroprotective effect of icariin on spinal cord injury in rats. Zhongguo $\mathrm{Gu}$ Shang 2018;31:1054-1060. https://doi.org/10.3969/j. issn.1003-0034.2018.11.014

33. Wang $\mathrm{Y}$, Li W, Wang M, et al. Quercetin reduces neural tissue damage and promotes astrocyte activation after spinal cord injury in rats. J Cell Biochem 2018;119:22982306. https://doi.org/10.1002/jcb.26392

34. Kandhare AD, Shivakumar V, Rajmane A, Ghosh P, Bodhankar SL. Evaluation of the neuroprotective effect of chrysin via modulation of endogenous biomarkers in a rat model of spinal cord injury. J Nat Med 2014;68:586603. https://doi.org/10.1007/s11418-014-0840-1

35. Oztanir MN, Ciftci O, Cetin A, Aladag MA. Hesperidin attenuates oxidative and neuronal damage caused by global cerebral ischemia/reperfusion in a C57BL/J6 mouse model. Neurol Sci 2014;35:1393-1399. https:// doi.org/10.1007/s10072-014-1725-5

36. Kamisli S, Ciftci O, Kaya K, Cetin A, Kamisli O, Ozcan C. Hesperidin protects brain and sciatic nerve tissues against cisplatin-induced oxidative, histological and electromyographical side effects in rats. Toxicol Ind Health 2015;31:841-851. https://doi. org/10.1177/0748233713483192

37. Ishola IO, Afolayan O, Odutola OI, Odutola IO, Faniyan O, Adeyemi OO. Therapeutic potential of hesperidin in Parkinson's disease with dementia: inhibition of alpha synuclein and amyloid beta in Drosophila melanogaster. Niger J Physiol Sci 2021;36:43-48.

38. Semis HS, Kandemir FM, Kaynar O, Kaynar O, Dogan T, Arikan SM. The protective effects of hesperidin against paclitaxel-induced peripheral neuropathy in rats. Life Sci 2021;287:120104. https://doi. org/10.1016/j.lfs.2021.120104 
39. Noshy PA, Azouz RA. Neuroprotective effect of hesperidin against emamectin benzoate-induced neurobehavioral toxicity in rats. Neurotoxicol Teratol 2021;86:106981. https://doi.org/10.1016/j. ntt.2021.106981

40. Heo SD, Kim J, Choi Y, Ekanayake P, Ahn M, Shin T. Hesperidin improves motor disability in rat spinal cord injury through anti-inflammatory and antioxidant mechanism via Nrf-2/HO-1 pathway. Neurosci Lett 2020;715:134619. https://doi.org/10.1016/j. neulet.2019.134619

41. Yurtal Z, Altug ME, Unsaldi E, Secinti IE, Kucukgul A. Investigation of neuroprotective and therapeutic effects of hesperidin in experimental spinal cord Injury. Turk Neurosurg 2020;30:899-906. https://doi. org/10.5137/1019-5149.JTN.29611-20.2

Etik kurul onayı: Çalışmaya, Zonguldak Bülent Ecevit Üniversitesi Tıp Fakültesi Hayvan Deneyleri Yerel Etik Kurulu'nun 08.05.2013 tarih ve 2013/04 no'lu kararı ile onaylanmıştır.

\section{Teşekkür}

Çalışmamızın patoloji sonuçlarına katkısından ötürü Prof.Dr. Burak Bahadır'a, biyokimyasal sonuçlardaki katkısından ötürü Prof.Dr. Murat Can'a ve çalışmanın yürütülmesindeki katkılarından dolayı Prof.Dr. Şanser Gül'e teşekkür ederiz.

\section{Yazarların makaleye olan katkıları}

Veri Toplanması ve İşlemesi: H.A.A.

Analiz ve Yorum: E.K.

Literatür Arama: H.A.A. ve E.K.

Yazıyı Yazan: H.A.A.

Eleştirel İnceleme: E.K. 